\title{
Perception of Christianity and Christian Peers in the Drawings of Muslim Children: The Example of Pforzheim/Germany ${ }^{1}$
}

\author{
Yasemin Güleç ${ }^{2}$
}

\begin{abstract}
The purpose of this study is to ascertain the perceptions of Muslim children aged between 9 and 15 years old about Christianity and their Christian peers via drawings they draw. In total, 57 students participated in this research. The pattern of the study is based on art-based research listed among the qualitative research methods. The data were collected by the descriptive analysis of semistructured interviews as well as semiotic analysis of the drawings. It was observed that children use an "icon" the most in their drawings since it has a literal meaning, secondly the "index", which implies a causal relation while the children use the "symbol" the least. It is comprehended that the drawings of children reflect the inner world of the children. The drawings of children, stating that the religion does not constitute an important factor and they are not bothered to live with people from other religions, reflect the indicators based on the tolerance. On the other hand, the drawings of those who expressed that they are not content to live in a Christian society and that the religion is important for them, reflect the indicators based on the prejudice.
\end{abstract}

Keywords: Religious prejudice and tolerance, religious social categorization, perception of muslim minority group, children's drawings, semiotics.

\footnotetext{
${ }^{1}$ This article was presented as a verbal statement in the 3rd International Symposium on Civilization and Living Together, held on May 17-22, 2017 in Spain.

2 Dr. Yasemin Güleç, Hacı Bektaş Veli University, Faculty of Theology, Department of Philosophy and Religious Sciences, yasemingulec8@gmail.com, ORCID:0000-0001-8843-3270
}

Received: 08.03.2018, Accepted: 30.04.2019 


\title{
Müslüman Çocukların Resimlerinde Hristiyanlık ve Hristiyan Akran Algısı: Pforzheim/Almanya Örneği
}

\begin{abstract}
$\ddot{O}_{z}$
$\mathrm{Bu}$ araştırmanın amacı, 9-15 yaş Müslüman çocukların, diğer dine ve diğer dinden akranları hakkındaki algılarını, resimleri yoluyla tespit etmektir. Bu araştırmaya 57 öğrenci katılmıştır. Araştırma, nitel araştırma yöntemlerinden; sanat temelli araştırma ve yarı-yapılandırılmış görüşme desenleriyle desenlenmiştir. Veriler, resimlerin göstergebilimsel analizi, yarı-yapılandırılmış görüşmelerin betimsel analizi ile toplanmıştır. Çocukların çizimlerinde, en çok düz anlamı içeren "görüntüsel gösterge"yi kullandıkları, ikinci olarak neden-sonuç ilişkisi içeren, "belirti göstergesi" ni kullandıkları, en az kullanılan gösterge türünün ise "simge" olduğu görülmüştür. Araştırmada çocukların iç dünyalarının resimlere yansıdığı görülmektedir. Arkadaşının dininin önemli olmadığını ve diğer dinin mensuplarıyla birlikte yaşamaktan rahatsızlık duymadığını ifade eden çocukların resimlerine, hoşgörü temelli göstergeler yansımıştır. Öte yandan arkadaşının dinin önemli olduğunu ve Hristiyan bir toplumda yaşamaktan memnun olmadığını ifade edenlerin resimlerine ön yargı temelli göstergeler yansımıştır.
\end{abstract}

Anahtar Kelimeler: Dini önyargı ve hoşgörü, dini sosyal kategorizasyon, müslüman azınlık grup algısı, çocuk resimleri, göstergebilim. 


\section{Introduction}

Since the drawings are considered as a reflection of children's inner world, they help us understand the personality traits, interpersonal relationships, emotional problems, frustrations, fears, expectation etc. In children's drawings, while the emotions between the ages of 4 and 7, referred to as "pre-schema period", are expressed in a concrete form, the number of abstract expressions used in the drawings starting from the age of 9 seems to increase (Ives, 1984). Hence, the period between age 8 and 9 is called the " "schematic period", in terms of development stages of children's drawing. In this period, children start to acquire a unique perspective. The schema is formed by the perception of the children, the emotional meaning attached to that thing as well as the experiences about the thing. The child addresses here not only the personal relationships but addresses the rational relationships with others as well (Yavuzer, 2013). This period is called the "period of realism" since children, who are between 9 and 12 years old, usually approach the drawing with a realistic understanding. Hence, the drawings drawn during this period are based on observations, specific to the adults. The child compares his/her drawings with what s/he observes in nature and intends to imitate what s/he observes. If s/he fails to imitate, s/he may feel desperate. The ages between 12 and 14 are characterized by "naturalism". Most of the adults cannot access this phase. Because the child abandons drawing, by getting discouraged since s/he cannot draw the realistic view of nature in the previous phase. When they are 13-15 years old, it is observed that the children, who continue drawing, may fully use and effectively the perspective. Hence, there are more details in the drawings. They start to create abstract images (Malchiodi, 1998).

People interpret with his/her own perspective the religious, cultural and symbolic images that have been recorded in the mind since the person is born, according to the positive or negative effect of many factors including the family structure, educational background, social environment, and many other similar factors. Drawing is possible by using the signs and these signs are generated from religious, symbolic, social and cultural backgrounds. Drawings, more than verbal modes of expression, provide the best means for projection of the unconscious levels of the individual's inner group (Abraham 1990). We may get help from the semiotic approach as the method to be used for analyzing and comprehending this language. That would help to comprehend the drawings in an integrated way (Ashwin, 1984). 
While children's drawings are mostly used in the fields of psychology and psychotherapy Frith \& Law, 1995; Malchiodi, 2001; Bahçıvan-Saydam, 2004; Sayıl, 2004) they are providing benefits in language (Demir, 2007) and mathematics (Bussi and Boni, 2003) education. In recent years, we observe that the children's drawings are used in many fields as a diagnostic tool to understand the children's knowledge and experiences from their point of view (Bayav, 2006; Cowan \& Albers, 2006; Ekinci, 2008; Leitch, 2008; Ersoy \& Türkkan, 2009; Ersoy \& Türkkan, 2010; İşliyen \& İşleyen, 2015;Öksüz, Güven, Baba \& Kartal, 2015; Ersoy, 2016). There are many studies conducted by analyzing the children's drawing in order to understand the perceptions of children on violence (Yurtal \& Artut, 2008; Akbulut \& Saban, 2012) the effects of migration (Ekinci, 2008) and war (Ben-Asher, 2016), familial situation (Akalın 2008; Dülger, 2008; Türkcan, 2013) and hospitalization (Şen-Beytut, Bolışık, Solak, \& Seyioğlu, 2009; Durualp, Çiçenoğlu, Mümünoğlu, Kalkanlı, \&Altuntaş, 2012).

Children's drawings are also used as a diagnostics method in researching the development of religious and moral concepts in children. Regarding children's religious development, some religious concepts such as god (Harms, 1944; Pnevmatikos, 2002; Zengin, 2010), heaven-hell (Koç 2008; Ulçay 2011) and death (Tümlü, 2013) have been examined in semiotic approaches.

In terms of moral development, in the context of tolerance and prejudice in children, the most important differences that may cause tension between groups, especially in multicultural societies, are race, ethnicity (White \& Gleitzman, 2006; Lovini \& Carlson, 1985; Doyle \& Aboud, 1996; Kistner, Metzler, Gatlin, \& Risi, 1993) and religious differences (Verkuyten \& Thijs, 2010; Velasco González, Verkuyten, Weesie, \& Poppe, 2008; Takriti, Barrett, \& Buchanan-Barrow, 2006; van der Straten Waillet \& Roskam, 2012a; van der Straten Waillet \& Roskam, 2012b).

Comparisons have been made between children's drawings of different ethnic and racial groups to examine the impact of social status, political conditions and social concepts (Teichman, 2001; Teichman \& Zafrir, 2003; Laor, Wolmer, \& Cohen, 2004; Michael \& Rajuan, 2009; Yedidia \& Lipschitz-Elchawi, 2012). As far as we access, we have not found any study that 
investigated the perceptions of Muslim children towards their Christian peers through the drawing method.

Religion is of great importance in many people's lives, and religious groups are among the more salient buttresses of identity (Altemeyer, 2002). Religious groups are of great importance in the lives of children in terms of supporting the development of both individual and group identity (Seul, 1999). Additionally, questions about religious diversity increase and may cause social divisions and new conflicts (Verkuyten, 2007). Studies in the field of religious group categorization and attitudes were fewer than those of race and ethnic groups. Therefore, it is important to conduct more research among religious groups. In this sense, the contribution of the present research to the literature is important. Because of the limited research on religious intergroup differences, other inter-group literature will also be utilized while discussing the results of the study.

The main purpose of this study, which strives to analyze the perceptions of children on other religions and members of other religions through their drawings and uses art as a diagnostic method, is to determine how students perceive Christianity and their Christian peers and reflect this perception in their drawings. Answers to the following questions are sought in the study: i. which types of indicators did the students use in their drawings? ii. What differences are there in the drawings of the students in terms of cognitive development and age? iii. How did the religious tolerance and prejudice perceptions of religious minority children living in multicultural societies reflect in their drawings?

The data were classified based on Peirce's semiotic theory, as "icon, index and symbol" (Erkman, 1987). It was firstly seen that the children used the "icon" which includes the direct and real meanings of the object. Secondly, they used the "index" which_based on the reason-result relationship. Lastly, they used the "symbol" which based on the symbolic meaning of the object in their drawings.

In parallel with the literature on children's drawings, the children's inner worlds were reflected (Teichman, 2001; Teichman \& Zafrir, 2003; Akalin, 2008; Michael \& Rajuan, 2009; Akbulut \& Saban, 2012; Yedidia \& Lipschitz -Elchawi, 2012; Türkcan, 2013; BenAsher, 2016) on their drawings in this study. With age and cognitive development, it is seen that the details in drawings increase (Harms, 1944; Golomb, 1987; Brown, 1990; 
Pnevmatikos, 2002; Cox, Perara, Koyasu, \& Hiranuma, 2001; Ulçay, 2011; Tümlü, 2013; Zengin, 2010).

In some studies that reached the same conclusions as ours, it was seen that children's racial (Goodman, 1952; Aboud, 1988; Doyle \& Aboud, 1993) and religious prejudices (van der Straten Waillet \& Roskam, 2012a) decrease as their ages increases. This is because they develop the ability to empathize with others and recognize different perspectives. In the literature, there are conclusions that it is not enough to explain the development of perceptions of ethnic, racial and religious tolerance and prejudice in children and adolescents based only on age and cognitive development (Elkind, 1964, 1970). The development of tolerance and prejudice may be influenced by the heterogeneity and homogeneity of schools and classes, group status, contacts among groups and ethnic, racial and religious socialization practices of parents (Allport, 1954; Kistner et al., 1993; Pettigrew \& Tropp, 2006; Takriti, Barrett, \& Buchanan-Barrow, 2006; van der Straten Waillet \& Roskam, 2012a; van der Straten Waillet \& Roskam, 2012b; Verkuyten \& Thijs, 2010).

\section{Method}

\section{Sample}

The criteria sampling method was used for selecting the students to take part in the study. Subjects were selected according to some criteria. i. Being born and raised in Germany ii. Being a Muslim iii. Being a child of a Muslim family, immigrated to Germany from Turkey iv. Being educated in German public schools v. Being between 9 and 15 years old vi. Willing to participate in the study. 57 students from the German school in Pforzheim and its surrounding participated in the study. Table 1 shows the distribution of the students by school, age and gender. While 39 students are female, 18 students are male.

\section{Table 1}

The Distribution of the Students by School, Age and Gender

\begin{tabular}{lllll}
\hline & Gender & Age \\
School & Female & Male & $9-10$ & $11-15$ \\
\hline Grundschule (Primary school) & 10 & 3 & 13 & - \\
Realschule (Secondary School) & 19 & 6 & - & 25 \\
Gymnasium & 10 & 9 & - & 19 \\
Total & 39 & 18 & 13 & 44 \\
\hline Grand Total & 57 & & & \\
\hline
\end{tabular}


While 13 students are studying at level Grundschule (Primary School), 25 are studying at Realschule and 19 students are studying at Gymnasium ${ }^{3}$ level. While 13 of the students are between the ages of 9 and 10, 44 students are between the ages of 11 and 15 .

\section{Analysis of Data}

The data was collected through children pictures, interview about pictures and semistructured interview methods. The research was carried out in two stages. Firstly, the students were asked to draw the first thing that came to their minds when we mention "Christianity and Christian friends". Then, the students were interviewed about their drawings in order to comprehend what they really express with the drawing. Since most of the students have struggled to express their feeling and thoughts about Christian peers by using only symbols, we have asked 2 open-ended questions to the participants, as the part of the semi-structured interview: i. How do you feel about Christianity (good, bad, middle, very bad, hate, etc.) Can you explain us the reasoning behind your feeling? ii. Is the religion of your friend important for you? Why?

Classification of the icons used by students in their drawings has been determined according to the interviews conducted with the students on the drawings and the elements that the drawings contain. The data were classified according to Pierce's semiotic theory, as "icon, index, and symbol" (Erkman, 1987). If the elements included in the drawings are expressed with their lateral and real meaning, they are classified as "icon". If they include a causeeffect relationship, the drawings are classified as "index" while they are classified as

\footnotetext{
${ }^{3}$ The first step of a compulsory school education in Germany is Grundschule (Primary school). Usually covers a duration of 4 years (In Berlin and Brandenburg states, it lasts 6 years.) According to the level of success, the students are classified into schools; hauptschule, realschule or gymnasium. By taking into account the grades of the second semester in the 4th grade as well as the average of written and oral grades of the beginning of the second semester, an average is calculated and the selection is based on this average. The pupil is entitled to enter the Gymnasium, if the average of German and Mathematics grades in the second semester of 4th grade is between 1.0 and 2.5. If the average is between 2,6 and 3,0, the pupil is entitled to study in Realschule. Finally, if the average is below 3.1, the pupils study in Hauptschule. (Bildunsplan 2004,Grundschule, BW Ministerium für Kultus Jugend und Sport, Bildungspläne der Allgemein Bildenden Schulen.Cd document; quoted, Perşembe, 2010).
} 
"symbol" if expressed in a symbolic sense. Two themes emerge from the answers given to the open-ended questions that were asked the students. Students' views adopting a tolerant or prejudicial approach to Christianity and Christian peers have been analyzed with descriptive analysis supported by the drawings of the children.

\section{Results}

\section{Use of Indicators by the Students}

Table 2

Distribution of Indicators Used in Drawings by Schools

\begin{tabular}{lllll}
\hline & $\begin{array}{l}\text { Type of School } \\
\text { Grundschule } \\
\text { (Primary }\end{array}$ & & & \\
Indicator Type & school) & Realschule & Gymnasium & Total \\
\hline Icon & 7 & 18 & 7 & 32 \\
Index & - & 2 & 5 & 7 \\
Symbol & - & - & 2 & 2 \\
Icon + Index & 5 & 5 & 5 & 15 \\
Icon + Index + Symbol & 1 & - & - & 1 \\
\hline Grand Total & 13 & 25 & 19 & 57 \\
\hline
\end{tabular}

As observed in Table 2, students preferred to express their perceptions of the concepts of "Christianity and Christian peers" by using the icons the most. The second visual indicator that the students used is the "icon and index" indicator. The third indicator used by the students is the "index" icon. However, the visual indicator that was used the least is the "symbol". There is only 1 student, who used all the indicators together. When the information in Table 2 and Table 3 are evaluated together, 6 out of 13 Grunschule students have drawn a single icon (the sign of the cross). Of the 25 Realschule students, 4 students only draw a sign of the cross. Only one of the 19 gymnasium students used the "sign of the cross" as the single icon. Almost all of the students of Realschule and Gymnasium schools used more than 2 icons together. However, none of the Grundschule (primary school) students, who use the icon indicator in their drawing, had used more than 2 icons together. 
Table 3

Distribution of Visual Indicators by Schools

\begin{tabular}{llll}
\hline & $\begin{array}{l}\text { Type of School } \\
\text { Grundschule } \\
\text { (Primary school) }\end{array}$ & Realschule & Gymnasium \\
\hline Icons & 6 & 9 & 1 \\
\hline The sign of the cross & - & 2 & 5 \\
\hline The sign of the cross + Crucifixion & - & - & 1 \\
\hline The sign of the cross + Bible & 5 & 4 & 4 \\
\hline The sign of the cross + Pig & 1 & 1 \\
\hline Church & - & 1 \\
\hline Church + The sign of the cross & & \\
\hline $\begin{array}{l}\text { The sign of the cross }+ \text { Crucifixion }+ \text { Church } \\
\text { Bell + Jesus } \\
\text { Alcoholic Beverage }+ \text { Candle }\end{array}$ & & \\
Bible + Pope \\
$\begin{array}{l}\text { God + Christmas } \\
\text { Pig }\end{array}$
\end{tabular}

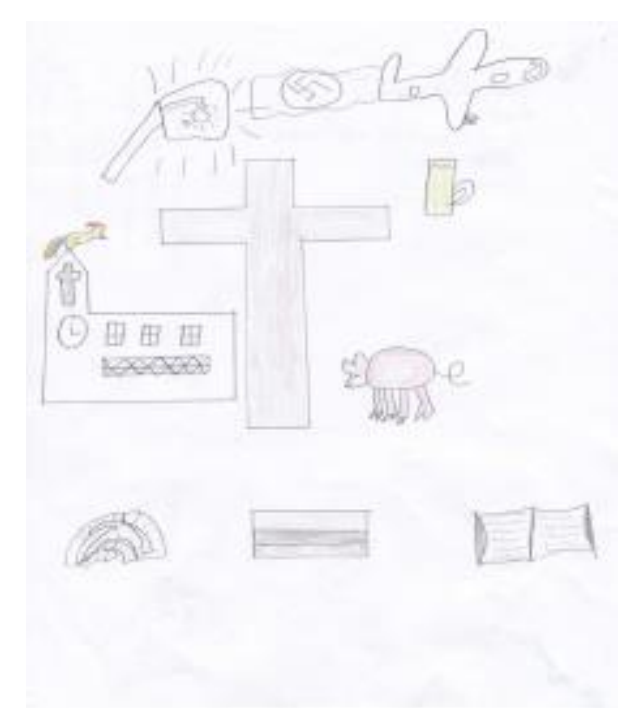

Figure 1. Student 1 (S1) Male/12 Gymnasium

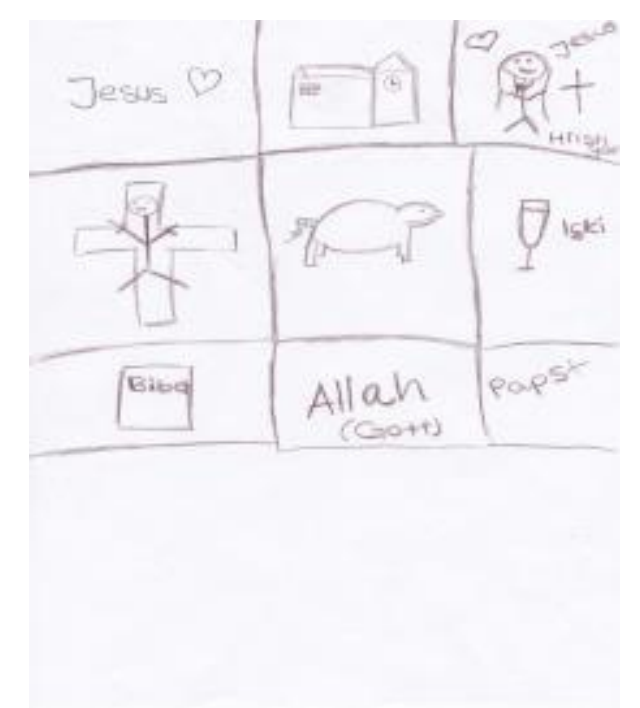

Figure 2. Student 2 (S2) Female/13 Gymnasium

Above you may find the examples of interviews and semi-structured interviews with two students, using at least 4 icons together. As observed in Figure 1, S1 has used several visual indicators together with the concept of "Christianity and Christian peer". When interviewed, S1 stated, "when you mention Christianity, the things the come to my mind are, the sign of the cross, the Bible, the church, the pews in the church, praying hands, the fact that they 
drink a lot of alcoholic beverages and they eat pork meat." S1 replied to the open-ended question as follows, "when Christianity and my Christian friend are mentioned, good feelings are evoked. Because they are mostly good people. Because the religion of the person that I want to be friend with is not important, but the morality of the person matters to me." S2 stated, "What the Christianity evokes; I have drawn these images for Jesus, the sign of the cross, the Crucifixion, the Bible, the church, the pig, the Pope, the God. ". When replying the open-ended questions, S2 answered, "I am happy to live in a Christian society. Because I have many good Christian friends. I always learn something from them."

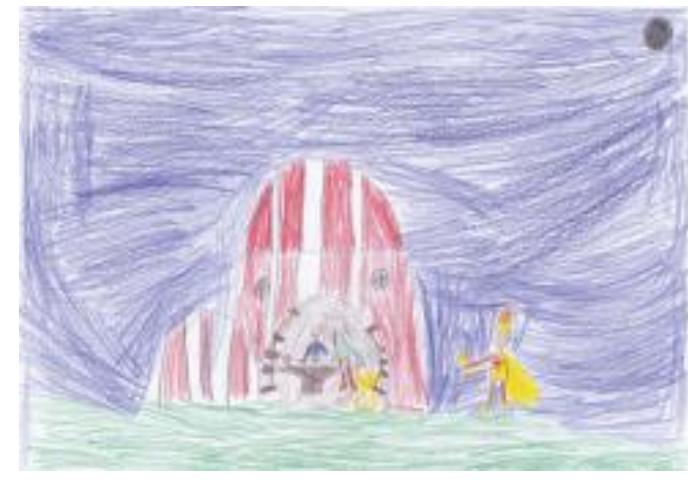

Figure 3. Student 3 (S3) Male/11 Gymnasium

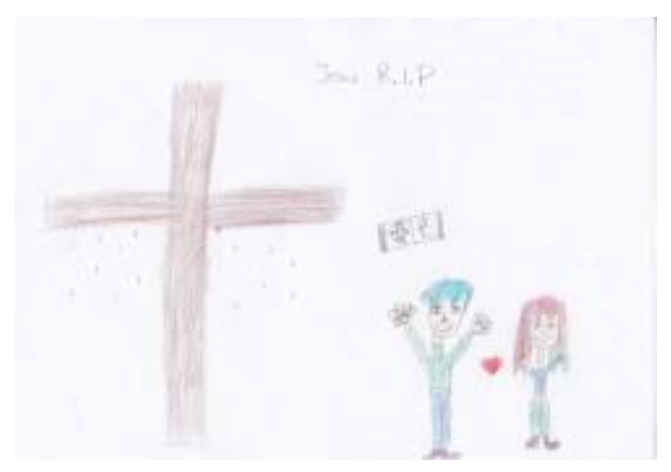

Figure 4. Student 4 (S4) Female/13 Gymnasium

Above is an example of the interviews of two students using their "icon" as the indicator in their drawings and their interviews with their semi-structured interviews. S3 states during the interview, "Jesus is believed to be a Prophet. And they brought gifts from gold to celebrate his birth." When we asked where he learned this information, he responded, "One day I attended a religious lesson for Christians and the teacher told me about it, For this reason, I remembered when you asked about the Christianity and I drew this drawing." It is understood here that S3 uses an "index" as the indicator since he established a causal connection between the birth of Jesus and gold gifts. When replying the open-ended questions, he replied, "I am not bothered to live here. Because I have many very good friends. The religion is not important for me as long as my friend is a nice human being." During the interview with S4, she states, "The sign of the Cross explains the suffering of the Prophet Jesus. That is why I put some blood on the sign of the cross. R. I. P (rest in peace), this is something people say for Jesus. I drew a boy and a girl being friends since flirting is not a sin for Christianity. I also added Bible, these are all that come to my mind." Here, the student used "index" since she established a causal relationship between the 
suffering of Jesus and blood drops and the friendship between the girl and boy and the fact that flirting is allowed. She responded the open-ended questions as follows, "I remember good things when I think about Christianity. I do not know the reason why. It is enough for me if my friends are nice."

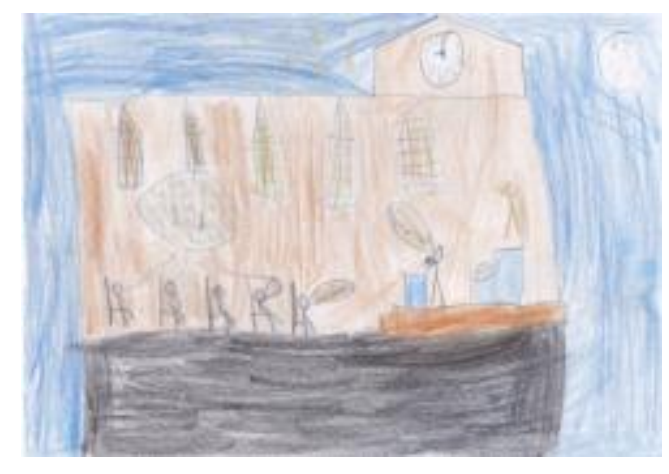

Figure 5. Student 5 (S5) Male/11 Gymnasium

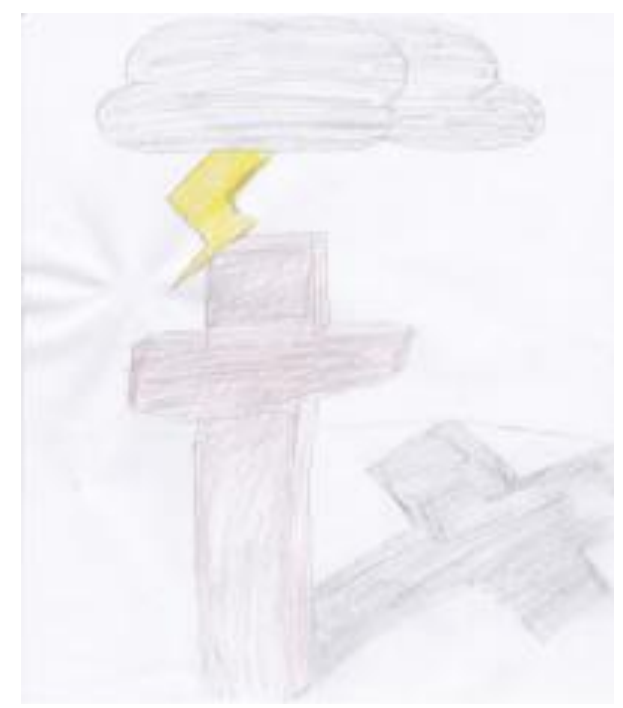

Figure 6. Student 6 (S6) Female /11 Realschule

Above is an example of the interviews and semi-structured interviews of the two students, who used the "icon and index" indicators together. S5 explains his drawing by saying, "People are singing in the church and there is a very beautiful sound in the moonlight." The student draws a church and benefits from an icon in the first place. However, since S5 states that a divine voice is coming from the church in the moonlight, it is understood that he establishes a positive causal relationship (the divine voice coming from the church - a beautiful voice) and hence, he uses the "icon and index" indicators together. When replying the open-ended questions, he said, "I do not feel anything bad when Christianity is mentioned. In fact, I have a beautiful and nice feeling about this. It is enough for me if my friends are nice because there are many Muslims, who are not nice." S6: "The sign of the Cross is struck by lightning. Because they have changed the Bible.", she replied. Here the S6 used the icon, the most well known visual indicator among others. However, she establishes a causal relationship between the sign of the cross, struck by lightning and the fact that the Bible being changed. The student asked open-ended questions by stating, "I do not have a good feeling about Christianity, I never thought of becoming a Christian. However, the most important thing for me in a friendship is behavior." As mentioned above, only 2 Gymnasium students, out of 57 students, used the "symbol" indicator in their drawings. 


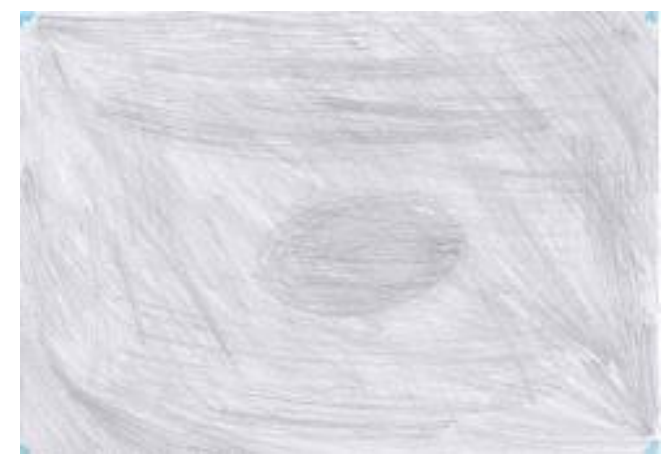

Figure 7. Student (S7) Female/12 Gymnasium

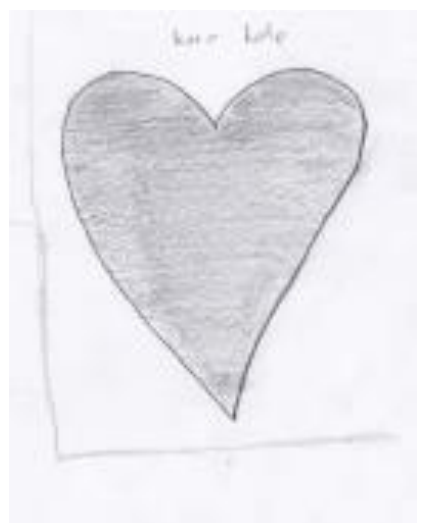

Figure 8. Student 8 (S8) Female/12 Gymnasium

Above, you may find the interviews and semi-structured interviews conducted with these students. As you can observe in Figure 7, S7 completely scribbles the whole page and scribbles an ellipse in the middle of the page in a darker color. When replying during the interview, she states that she had bad feeling and thoughts about Christianity and that is why she scribbled the page. She responded to the open-ended question by saying, "I do not like Christians and I do not have good feelings for them, they are not like us, I like my own cultural values. It is important to me that my friend shares my culture." When we looking at the drawing of S8, we observe a black heart figure. During the interview, S8 explains her drawing by saying, "I do not trust Christians, that is why I draw a black heart". When responding the open-ended questions, she states, "I do not have a good feeling about Christians. Because they do not trust me." Here, both students expressed their perception by using "a black page and a black heart", as they perceive the subject in their own world.

\section{Religious Tolerance and Prejudicial Perceptions of Students}

Table 4

Students' Approach to Christianity and Christian Peoples by Age

\begin{tabular}{llll}
\hline Age & Tolerant Approach & $\begin{array}{l}\text { Prejudicial } \\
\text { Approach }\end{array}$ & No-idea \\
\hline $9-11$ & 10 & 11 & 2 \\
$12-15$ & 22 & 7 & 5 \\
Total & 32 & 18 & 7 \\
\hline
\end{tabular}

Table 4 contains the distribution by age of the answers to the open-ended questions in terms of tolerant and prejudicial approach. Of the 57 students, who participated in the study, 32 
expressed their perspectives on "Christianity and Christian peer" with a tolerance-based approach. 18 students have a prejudicial approach in this regard. 7 students did not disclose any ideas. It appears that students become more tolerant as they grow older. While 10 out of 21 students (aged 9-11) (48\%) have a tolerant approach, 22 out of 29 students aged 12$15(76 \%)$ adopt a tolerant approach.

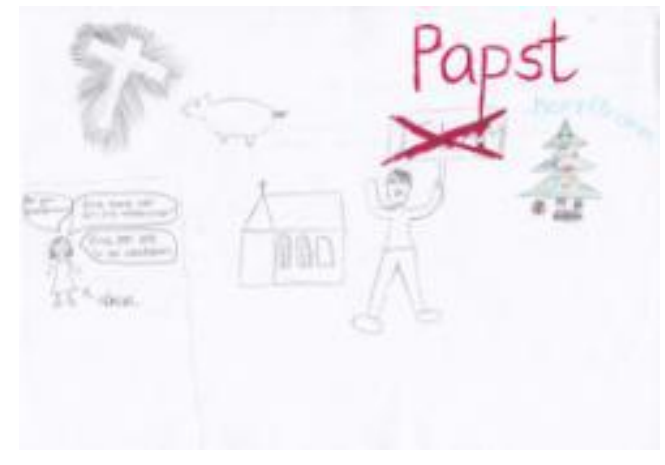

Figure 9.Student (S9) Female/13 Gymnasium

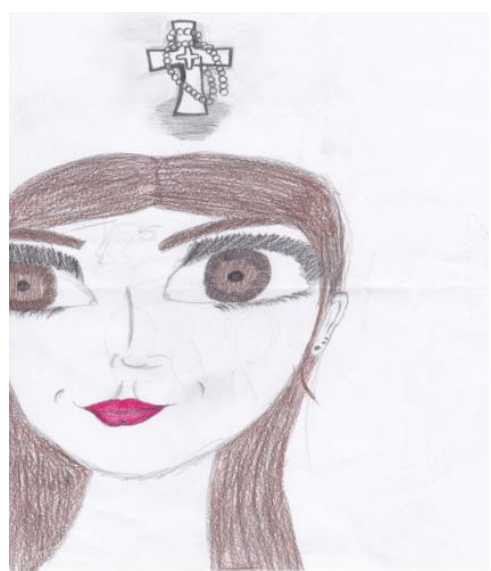

Figure 10.Student 10 (S10) Female/13 Gymnasium

Above, we have given examples of drawings and semi-structured interviews of some students, who have adopted a tolerant approach in their perceptions of other religions and peers of other religions. S9 explains her drawing by stating, "Some Christians do not accept and respect Islam as religion, while others would like to stop Islam since they think this is a dangerous religion." She responded to the open-ended question as follows, "Although some of my German friends do not like Muslims, I consider Christians as nice people. I do not feel bad when someone mentions Christianity. I prefer to be friends with people of a different religion. Because I am curious about different cultures and I want to learn new things." When we asked S10 about the portrait in the drawing and the sign of the cross, she replies, "I love my Christian friend. Because she is a very good person. That's why I drew her and decorated the drawing with the sign of the cross for my friend." Hence, it is understood that the student uses the "index" indicator in his drawing, establishing a causal relationship between Christianity and her beloved Christian friend. In addition, the student responded in the same way to the open-ended questions that were asked of her. She expressed that she was happy with his Christian friends and that she was considering the morality of the persons as the criteria to be friends. Thus, from the points of view shared with us, we understand that S10 has a tolerant approach. 


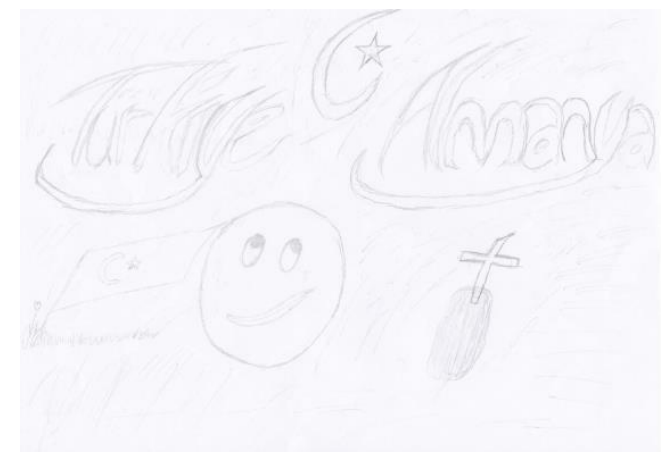

Figure 11. Student 11(S11) Female/14 Realschule

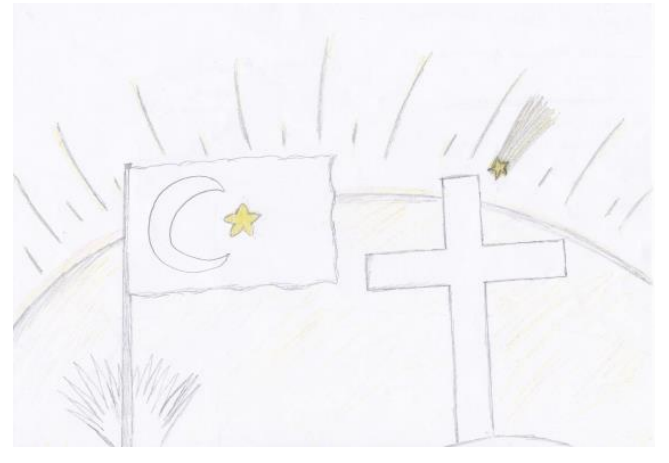

Figure 12. Student 12 (S12) Female/13 Realschule

It seems that S11 and S12 have drawn the same theme (tolerant approach) in their drawings. Both S11 and O12 explain their drawings by saying, "There are unity and cooperation between Turkey and Germany." Here, the two students draw the sign of the cross and the Turkish flag side by side and express the unity between Turks (Muslim) and Germans (Christian) with their "index" indicator. S11 answered open-ended questions as follows, "I do not have a bad feeling for Christians. According to me, the religion of my friend is not important." S12 states, "Let people believe whatever they like to believe. In the end, we are all human and we will be the same after death." Hence, both students adopt a tolerancebased approach to other religions and members of other religions.

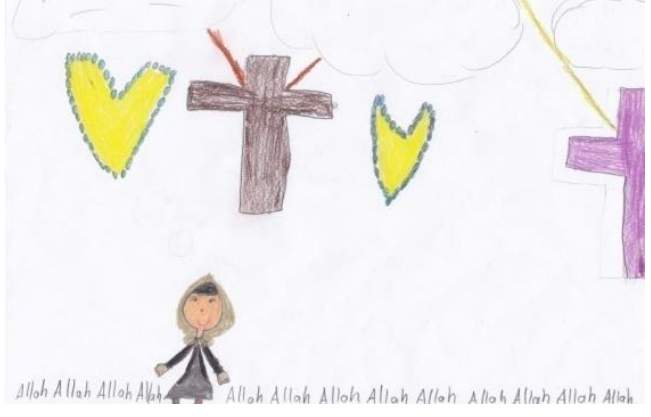

Figure 13. Student 13 (S15) Female/9 Grunschule

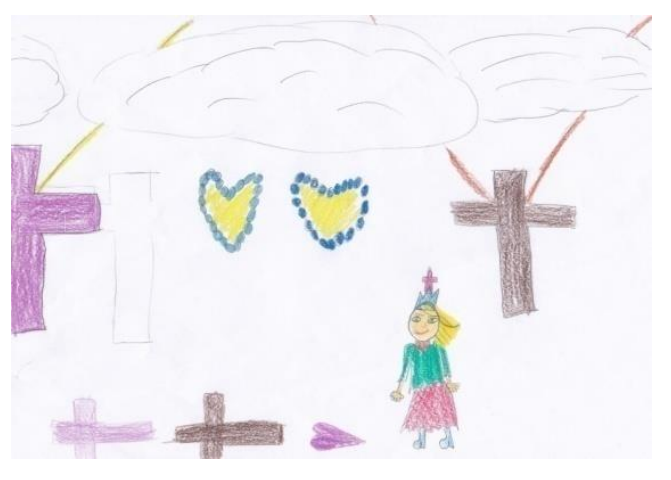

Figure 14. Student 14 (S14) Female/9 Grunschule

In Figures 13 and 14, two students ${ }^{4}$ sitting together have drawn the above pictures in such a way that they complement each other on two separate papers. It has been observed that

\footnotetext{
${ }^{4}$ Separate seats are provided for students so that they freely reflect their independent perceptions on paper and they are not affected by each other. However, it was observed in the weekly lessons of the researcher that these two students were always sitting and studying together. These students were allowed to sit together since they insisted on drawing together.
} 
students have the same perceptions about the subject when we interviewed the students. "The Muslim girl has a headscarf while the Christian girl has a sign of the Cross at her head. The girls in the drawing are friends and love each other very much." When asked the students the meaning of the heart, they replied, "The two friends do not want to be separated because they love each other so much." S13 and S14 replied to open-ended questions as follows, "We are friends with everyone who is nice, we have many Christian friends in school. We do not like Muslims, who are not nice."

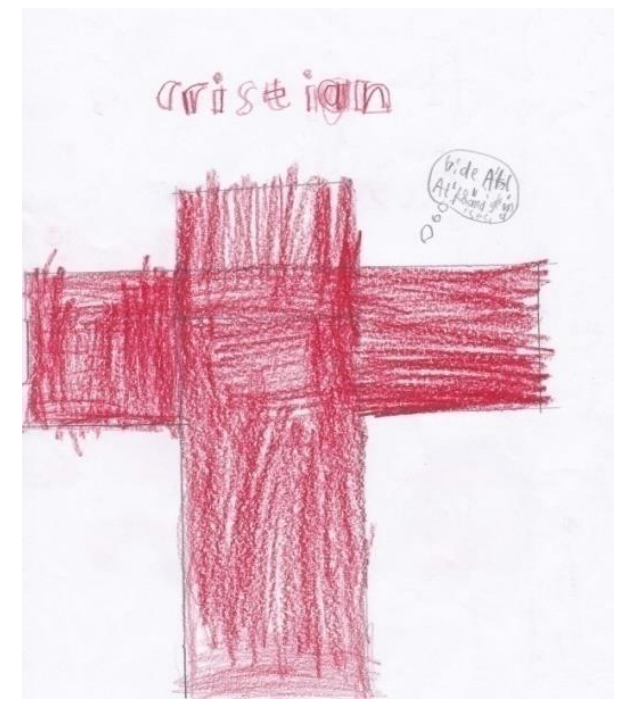

Figure 15. Student 15 (Ö15) Male/9 Grundschule

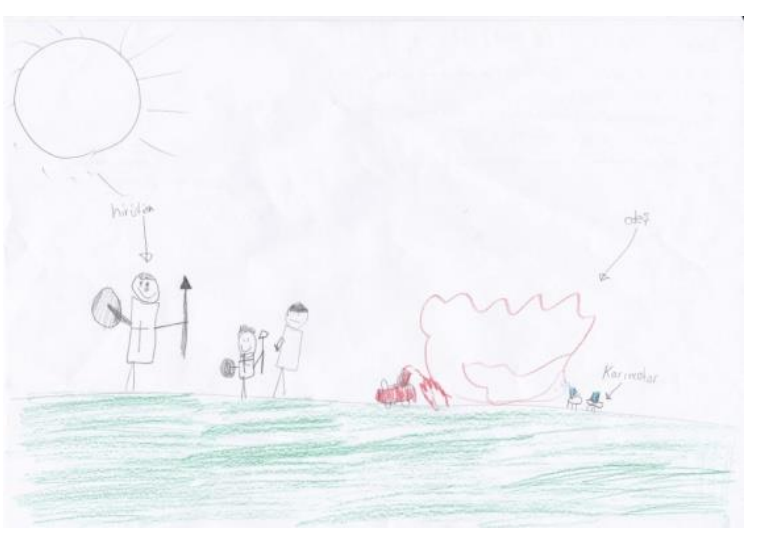

Figure 16. Student 16 (S16) Male/9 Grundschule

Above, you may find the drawings and interviews as well as semi-structured interviews of 2 students, adopting a prejudicial approach against other religions and members of other religions. Drawing 15 belongs to a Grunschule (primary school) student as shown above. S15 explained is drawing as follows, "The sing of the cross and the sound of the horses come to my mind. Because when Christians and Muslims were fighting, the Christians were unfair." When we asked how he acquired this information, he answered, "My mother told me while I was watching a movie." If we evaluate together the expressions and drawing, we can conclude that he uses the icon - the sign of the cross - and index (cause-effect, the unfairness of Christians, the war between Christians and Muslims) indicator together. When we asked the reason why he painted red the sign of the cross, S15 replied, "When I think about Islam, the green is the appropriate color to me. For Judaism, it is blue, and it is red for Christianity. That is why I painted the cross in red." S15 replied to open-ended questions by saying, "I feel bad about the sign of the cross". Likewise, the drawing 16 is drawn by a 
Grundschule student. S16 explained the drawing by saying, "The Christians wanted to throw the Prophet Abraham into the fire. The ants carried water to protect the Prophet, Abraham. I believe they do not believe in Prophet Muhammad." When we asked S16 how he acquired this information, he responded, "Before going to bed, my dad tells me stories. He told me about the story as well. That's why I drew it." When we evaluate his expressions and his drawing, we can conclude that S16 uses the icon - the sign of the cross, the index indicator (cause-effect/the Christians are mean and they throw Prophet Abraham into the fire) together. In addition, S16 prefers to express his thoughts with a symbol that is not directly related to the Christians today, like throwing Abraham on fire. In this sense, it is possible to state that S16 uses the icon, index and symbol indicators together. The student replied to open-ended questions by stating, "I feel bad when I thought about Christianity. According to me, the religion of the people is important, but it is also important to be nice." These results indicate that both S15 and S16 have a prejudicial approach.

\section{Discussion}

\section{Use of Indicators by the Students}

It is comprehended that the drawings of children reflect the inner world of the children. The students expressed their perception about the subject by using different icons, indexes, and symbols. While a student expresses a situation with "a sign of the cross", another student expresses the same situation by drawing a black heart. One states something by decorating with a sign of the cross; another student expresses the same situation by a lightning strike. These findings of the research resemble the findings of many researchers, which have ascertained that children's drawings reveal their inner worlds and their psychological states (Akalın, 2008; Şen-Beytut et al., 2009; Akbulut \& Saban, 2012; Türkcan, 2013; Öksüz et al., 2015; Ben-Asher, 2016). The studies of Ulçay (2011) reveal that many cases like separated families, unhappiness, fights, unity, etc. are reflected in children's drawings when they draw heaven and hell. When a boy draws himself with his mother in heaven while he draws his stepmother and his father in hell, we may think that the child stays with this father and he was forced to be separated from his mother and he contemplates about the day he is going to meet his mother in heaven. 
As it is possible to observe from the analysis, when we compare the drawings of the students between the ages of 9 and 10 and the students between the ages of 11 and 15, we realize that the drawings of students, who are between 11 and 15 years old, have more details in their drawings. Correspondingly, the findings of Brown (1990) and Golomb (1987) reveal that the number of detail used increases with age. When we analyze the drawings of children between 7 and 12 years old, we realize that the older children and girls use more details than the younger children and boys (Cox et al., 2001). Ulçay's (2011) study reveals that children intend to draw hell rather than heaven when they get older. When they are 7 and 8 years old, the children think, "I have never been in hell so I can't draw it." Then, when they are 9, they commence thinking, "I will be the one to draw the most horrible hell". Finally, they change their perspective when they are 12 and consider the concept in a more educational and informative way and they tend to ask, "who is going to hell" and "why she/he is going to is going to hell". In addition, the children depicted both sexes in heaven and hell, without gender discrimination when they are 7-8year-old, although they painted their fellows in heaven and opposite sexes in hell when they are 9-11 years old. Since the age 12, the ability to think abstractly begins to develop as well as the understanding of justice. Hence, the children begin to depict the fair judgment for the whole humanity in their drawings. A 14-year-old child has drawn a hell, presented the concept in a humorous way and enriched the drawing with speech bubbles: "When people follow the plate with the word "Welcome to Paradise" on the straight path, the Devil is entertained for fooling people by saying "Hello, babies are welcome". When the girl arrives at the heaven's door, she is happy and says "hurrah", but at the same time, as she has an altruist character, she prays for the persons on the bridge by saying "God help you!".

Tümlü's (2013) study reveals that most of the children between 5 and 12 years old expressed their perception of death with "religious elements" and "violent elements" while only children between 5 and 6 years old expressed their perception by using the monsters, dead cartoon characters, ghosts, skeletons, and non-living creatures.

Pnevmatikos (2002) classified the primary school students' drawings based on the basic ontology of the God concept: i. God is a real man living on earth. ii. ii. God is a spirit living in the universe. iii. God is a spirit. iv. God is a spirit, which lives in positive conditions (goodness, love, peace). It is observed that the conceptual hierarchy of young children is simpler than the conceptual hierarchies of older children. $55 \%$ of 1 st Grade students 
contemplate God as a real man living on earth while $56 \%$ of 2 nd Grade students believe the same thing. This rate falls to $3.7 \%$ in the fifth grade. The rate of students, who consider that God needs a material structure in the sky to live, is $15 \%$ in the first grade, but the ratio increased to $66,7 \%$ in older children. The proportion of those, who depict God as a spiritual being remains the same at $15-30 \%$ in all classes. Those, who contemplate God as a good soul, constitute only $6.3 \%$ of the class in the 4 th grade.

According to Harms, children between the ages of 3 and 6 draw God as follows; Either as a king or father of all children, with long beard or no beard, either in a house made of gold on the clouds or in a house made of clouds, either in the shape of Crucified Jesus or in the shape of cloud with a polar bear depicted as the word "God", the formal language in which the divine experience is expressed in this period is always like a "fairy tale". However, children at the age of 7 and 11 do not have fairy tale elements in God's imaginations. Metaphysical imagination in the child was replaced by the reality. In this period, the child, in general, depicts the concept of God with religious symbols. In particular, every child used the Crucifix in his/her imagination. In addition, the Star of David, the priests as well as the intermediaries of God are among the most preferred symbols. Jesus prophet was drawn quite traditionally. Harms emphasizes that the formal character of children in this period is also observed in other artworks of children, in this sense the emotions of children reflected indirectly through symbols. Harms found many big differences when analyzing the drawings of 4,000 adolescents, aging between 12 and 18. This period is considered in three groups: the first group tends to experience the dominant religion in the society where the children live. The children of this group drew the sign of the cross, Mother Mary, the gates of heaven (doors to heaven), angels, the synagogues, Moses and burning bush. The children in this group do not have the religious imagination. The second group drew something original and personal. They described their thoughts with abstract, semi-abstract and symbolic drawings. They used abstract symbols such as light or sunlight, lightning in the dark sky. Finally, the third group of children has reflected their minds in astonishing ways. They have produced drawings, regenerating the religious and sectarian motifs, different from their own religious beliefs that the children have never experienced (Harms, 1944).

This study also proves that analysis of drawings can be used as a diagnostic method for determining the cognitive processes of children. When we compared the drawings of 
Realschule and gymnasium students in the same age range, it is observed that the gymnasium students use more visual indicators together than the Realschule students do. Moreover, it is also ascertained that gymnasium students use more than one visual indicator together, while at the same time the students that use the "symbol" indicator are gymnasium students. In this sense, it is possible to state that the students with a high level of academic knowledge have more advanced capabilities in terms of abstract thinking and for reflecting this thought. The study of Ulçay (2011) has found a positive relationship between the development of heaven and hell imagination and mental development, in parallel to the cognitive development of children. When the children are getting older, we observe the drawings with complex meaning, depicting abstract concepts including humor as well. When we analyze the drawings drawn by Muslim and Christian children about the concept of "God", we observe that the concept of God remains physical even though the Islamic education explains to the children in an abstract way a concept of God, who knows, sees and hears everything, who is free from space and who is everywhere. Because the cognitive development of the children is not yet sufficient to comprehend the abstract concept (Zengin, 2010).

\section{Religious Tolerance and Prejudicial Perceptions of Students}

Within the context of this study, we have discussed above the religious tolerance and prejudicial perceptions of students in the context of tolerance. In the analysis, there is a similarity between the answers given by the students to the open-ended questions and the perceptions reflected in their drawings. If we examine the drawings of the students stating that the religion is not important for friendship and they are happy to live together with members of other religions, we observe tolerant icons and symbols in their drawings. Similarly, the drawings of those, who say that religion is important for the friendship and they are not happy to live in a Christian society, include prejudicial icons and symbols. Hence, as mentioned above, the feelings, thoughts, and attitudes of children in terms of religious tolerant and prejudicial approach are reflected in the drawings, since the drawings constitute the reflection of children's inner world.

According to the findings, While $48 \%$ of students between 9 and 11 years old are adopting a tolerant approach, $76 \%$ of students between 12 and 15 years old adopt a tolerant approach. In parallel with the results of some previous studies, the perception of religious tolerance 
increases as the students' ages increase (van der Straten Waillet \& Roskam, 2012b; van der Straten Waillet \& Roskam, 2012a)

While $51 \%$ of the students between the ages of 9 and 11 years have a prejudicial approach, this rate drops to $24 \%$ in children between the ages of 12 and 15 years. It is possible to explain the decreased level of prejudice when the children grow older, by the development of children's abstract thinking ability and social interactions. Indeed, the 13-year-old S9 states; "Although some of the Christians do not consider Muslims well, I consider the Christians as good people. When I become a friend with someone from another religion, I learn a lot of things". We realize that S9 has interiorized a tolerant approach even most of the adults are not capable of. In the same way, the 13-year-old S10 decorates the drawing with the sign of the cross, to express the love for her friend. Moreover, S11 and S12 emphasize unity and solidarity by reminding everyone that they are human beings, ignoring the concept of other religion and race.

Van der Straten Waillet and Roskam's studies suggested that young children do not seem to be able to understand that their social environment could be categorized based on religious beliefs. This understanding is only reached in the middle of childhood at about 8 or 9 years of age while the vast majority of children growing up in a heterogeneous environment are likely to be aware of religious difference at 9 years of age, some children from religiously homogeneous environments do not acquire this awareness until 11 years of age. Children younger than 9 may know about some religious labels, but their understanding of these labels is likely to be inaccurate probably because of their cognitive limitations. Most young children think religious groups, like social groups, are based on physical or behavioral qualities, rather than the shared belief of group members (van der Straten Waillet \& Roskam, 2012b). While religious discrimination is often seen in childhood, it decreases in pre-adolescence and adolescence (van der Straten Waillet \& Roskam, 2012a).

In this study, the religious homogeneity and heterogeneity of the schools where the children attend were not asked. Attending homogeneous schools (Kistner et al., 1993; Rotenberg \& Cerda, 1994; van der Straten Waillet \& Roskam, 2012a; Verkuyten \& Thijs, 2010) may lead to greater confidence among the groups and development of positive relationships (Allport, 1954; Bornstein, 1989; Pettigrew \& Tropp, 2006; Velasco González et al., 2008). 
In this study, we observe some stereotypes in the drawings of the students, who adopt a tolerant approach. In the drawings of the students, there are evidently the usual symbols belonging to the Christianity such as the sign of the Cross, Church, Crucifixion, Jesus, Bible, Bell, etc. However, we observe in the drawings of some students some icons and symbols that are not directly related to Christianity, such as pigs and alcoholic beverages. Hence, we can say they include the alcoholic beverages since they are prohibited in Islam and the students reflect this in the drawings based on a religious stereotype, "Christians drink alcoholic beverages". Indeed, those who consume alcoholic beverages are not the Christians. Similarly, we can contemplate that the use of the pig symbol is because of a religious and cultural "stereotype". However, there are many other orders that are prohibited in Islam and allowed in the Christian lifestyle. In this sense, it is possible to say that the use of pig in the drawings reflects a cultural stereotype rather than a religious stereotype (since Muslims do not like pigs, think that the pigs are dirty and they would be appropriate for the Christians).

As mentioned above, many factors are effective in the development of prejudice and tolerance in children in addition to age and cognitive development. Prejudices are formed in children at very early stages by the influence of misconceptions and behaviors in the family, then reinforced by some discourses and social relationship, as well as media factors such as television and internet games (Allport, 1954; Hirschfeld, 1993; Bar-Tal, 1996; van der Straten Waillet \& Roskam, 2012a). In fact, when we asked about their sources of information to S15 and S16 (see the drawings 15 and 16), they stated that they learned from their parents. However, different results were reached in some studies that investigated the relationship between parent and child ethnic attitudes. While parent-child prejudices were associated with adolescence (White \& Gleitzman, 2006), small or insignificant correlations were found in childhood (Aboud \& Doyle, 1996; Carlson \& Iovini, 1985). Therefore, the effect of familial factors on the development of perceptions of religious prejudice and tolerance should be investigated in detail.

\section{Limitations}

It was planned to conduct this study bilaterally (Muslim / minority religious group Christian / majority religious group). However, some difficulties were encountered in 
getting permission from the families of the Christian students. So, the study was conducted unilaterally (only on Muslim students). The focus of the study was to inquire about the pictorial indicators of the majority group's religion and the effects of age and cognitive development on these indicators. For this reason, information could be obtained about the other factors affecting children's perceptions on religious tolerance and prejudice as much as the students expressed these.

\section{Conclusion and Suggestions}

This study attempted to determine the reflection of the perceptions of Muslim children aged between 9 and 15 years about Christianity and their Christian peers and used the students' drawings as a diagnostics method. The study revealed that semiotic analysis may be used as a diagnostics tool to comprehend students' feelings and thoughts in their inner world. In parallel to the age and cognitive development of the students, we observed that abstract thinking skills developed and they reflected this development better through drawing. In this sense, the art of drawing may be used as a diagnostics method in more studies in determining the development of religious and moral concepts in children.

In parallel to the results of some previous studies, in this study, the students' perceptions on religious tolerance increased, and their religious prejudice levels decreased with their age and cognitive development. There are conclusions in the literature that it is not enough to explain only with age and cognitive development the development of perceptions on ethnic, racial and religious tolerance and prejudice in children. For this reason, detailed research is needed to expand and integrate cognitive and social theories in the development of social understanding in children. Religious identity was measured by elements commonly used in social psychological research. However, the literature on different dimensions of religious identity is quite limited in terms of relationships, behaviors, and practices among religious groups. Future studies could be conducted on a variety of faiths and religious groups in different countries to investigate the development of religious categorization in children and various factors that affect this development. 


\section{References}

Aboud, F. (1988). Children and prejudice. New York: Basil Blackwell.

Aboud, F.E., \& Doyle, A.B. (1996). Parental and peer influences on children's racial attitudes. International Journal of Intercultural Relations, 20(3), 371-383.

Abraham, A. (1990). The projection of the inner group in drawing. Group Analysis, 23, 391402.

Akalın, T. (2008). Illköğretim 2. sınıf öğrencilerinin yaptıkları resimlerde aile içi yaşantılarının resimlerine yansıması. Yayımlanmamış yüksek lisans tezi. Gazi Üniversitesi, Ĕ̈itim Bilimleri Enstitüsü, Ankara.

Akbulut, M.G., \& Saban, A. (2012). İlköğretim öğrencilerinin şiddetle ilgili algılarının çizdikleri resimler aracılığı ile incelenmesi. Turkish Journal of Education, 1(1), 2137.

Allport, G. W. (1954). The nature of prejudice. Cambridge: MA: Perseus Books.

Altemeyer, B. (2002). Dogmatic behavior among students: Testing a new measure of dogmatism. Journal of Social Psychology, 142, 713-721.

Ashwin, C. (1984). Drawing, design, and semiotics. Design Issues, 1(2), $42-52$.

Bahçıvan-Saydam, R. (2004). Çocuk çizimlerinin klinik değerlendirmedeki yeri. Yansıtma: Psikopatoloji ve Projektif Testler Dergisi, 1(1-2), 111-124.

Bar-Tal, D. (1996). Development of social categories and stereotypes in early childhood: The case of "the Arab" concept formation, stereotype, and attitudes by Jewish children in Israel. International Journal of Intercultural Relations, 20, 341-370.

Bayav, D. (2006). Resimde göstergebilim, çocuk resimlerinin göstergebilimsel çözümlenmesi. Yayımlanmamış doktora tezi. Marmara Üniversitesi, Eğitim Bilimleri Enstitüsü, İstanbul.

Ben-Asher, S. (2016). Bedouin children and their reality perceptions of the war between Israel and Gaza. Journal of Muslim Minority Affairs, 36(4), 484-501.

Bornstein, R.F. (1989). Exposure and affect: Overview and meta-analysis of research, 19681987. Psychological Bulletin, 106, 265-289. 
Brown, E. (1990). Developmental characteristics of figure drawings made by boys and girls aged five through eleven. Perceptual and Motor Skills, 70, 279-288.

Bussi, M.G., \& Boni, M. (2003). Instruments for semiotic mediation in primary school classrooms. For the Learning of Mathematics, 23(2), 15-22.

Carlson, J.M., \& Iovini, J. (1985). The transmission of racial attitudes from fathers to sons: A study of Blacks and Whites. Adolescence, 20(77), 233-237.

Cowan, K., \& Albers, P. (2006). Semiotic representations: Building complex literacy practices through the arts. The Reading Teacher, 60(2), 124-137.

Cox, M., Perara, J., Koyasu, M., \& Hiranuma, H. (2001). Children's human figure drawings in the UK and Japan: The effects of age, sex, and culture. British Journal of Developmental Psychology, 19, 275-292.

Demir, M. (2007). Türkçe derslerinde metin çözümlemesine üslûp-bilim açısından yaklaşımüslûp çözümlemesinin okuma- anlamaya katkısı. Yayımlanmamış yüksek lisans tezi. Marmara Üniversitesi, Sosyal Bilimler Enstitüsü, İstanbul.

Doyle, A., \& Aboud, F.E. (1993). Social and cognitive determinants of prejudice in children. K. A. McLeod (Ed.), Multicultural education: The state of the art (s. 28-33). Toronto, Ontario, Canada: University of Toronto Press.

Durualp, E.E., Çiçenoğlu, S., Mümünoğlu, S., Kalkanlı, G., \& Altuntaş, Z. (2012). Hastaneye yatmış olan okul öncesi dönem çocuklarının yaptıkları resimlerin incelenmesi. Ĕgitim ve Öğretim Araştırmaları Dergisi [Journal of Research in Education and Teaching], 1(3), 249-260.

Dülger, N. (2008). 06-11 yaş öğrencilerin ailesel ve bireysel özelliklerinin resimlere yansıması, Yayımlanmamış yüksek lisans tezi, Süleyman Demirel Üniversitesi Sosyal Bilimler Enstitüsü. Isparta.

Ekinci, B. (2008). Göçe maruz kalmış 9-11 yaş çocukların kendilerini dışa vurma açısından resimlerin yorumlanması, Yayımlanmamış yüksek lisans tezi, İnönü Üniversitesi Sosyal Bilimler Enstitüsü. Malatya .

Elkind, D. (1964). Discrimination, seriation, and numeration of size and dimensional differences in young children. Journal of Genetic Psychology (104), 275-296. 
Elkind, D. (1970). The origins of religion in the child. Review of Religious Research, 12, 3542.

Erkman, F. (1987). Göstergebilime giriş. İstanbul: Alan Yayınları.

Ersoy, A.F. (2016). Dördüncü sınıf öğrencilerinin hoşgörü algısı ve deneyimleri: Bir fenomenolojik araştırma. Mersin Üniversitesi Eğitim Fakültesi Dergisi, 12(1), 454473.

Ersoy, A.F., \& Türkkan, B. (2010). İlköğretim öğrencilerinin çizdikleri karikatürlere yansıttıkları sosyal ve çevresel sorunların incelenmesi. Ĕgitim ve Bilim, 35(156), 96109.

Ersoy, A., \& Türkkan, B. (2009). İlköğretim öğrencilerinin resimlerinde internet algısı, 8(1), 57-73. Retrieved April 25, 2017, from http://dergipark.gov.tr/download/article-file/90891

Frith, C., \& Law, J. (1995). Cognitive and physiological processes underlying drawing skills. Leonardo, 28 (3), 203-205.

Golomb, C. (1987). The development of compositional strategies in children's drawings. Visual Arts Research, 13, 42-52.

Goodman, M. (1952). Race awareness in young children. Cambridge: MA: Addison-Wesley.

Harms, E. (1944). The development of religious experience in children. American Journal of Sociology, 50 (2), 112-122.

Hirschfeld, L. (1993). Discovering social differences: The role of appearance in the development of racial awareness. Cognitive Psychology, 25, 317-350.

İşliyen, F.Ş., \& İşleyen, M. (2015). Çocukların medya algısının resimler üzerinden analizi, Global Media Journal TR Edition, 5(10) Spring 2015, 271-287. Retrieved April 25, 2018, from http://globalmediajournaltr.yeditepe.edu.tr/makaleler/ GMJ_10. _sayi_bahar_2015/pdf/11-simsekIsliyenIsliyen.pdf.

İves, S.W. (1984). The development of expressivity in drawing. British Journal Education Psychology, 54, 152-159.

Kistner, J., Metzler, A., Gatlin, D., \& Risi, S. (1993). Classroom racial proportions and children's peer relations: Race and gender effects. Journal of Educational Psychology, 85(3), 446-452. 
Laor, N., Wolmer, L., \& Cohen, D. (2004). Attitudes toward Arabs of Israeli children exposed to missile attacks: The role of personality functioning. The Israel Journal of Psychiatry and Related Sciences, 41(1), 23-33.

Leitch, R. (2008). Creatively researching children's narratives through images and drawings. In P. Thomson (Ed.), Doing visual research with children and young people, 37-57. London and New York, Routledge.

Lovini, J., \& Carlson, J.M. (1985). The transmission of racial attitudes from fathers to sons: A study of Blacks and Whites. Adolescence, 20(77), 233-237.

Malchiodi, C.A. (1998). Understanding children's drawings. New York: The Guilford Press.

Malchiodi, C.A. (2001). Using drawings as intervention with traumatized children. Trauma and Loss: Research and Interventions, 1(1), 21-27.

Michael, O., \& Rajuan, M. (2009). Perceptions of 'the other' in children's drawings: an intercultural project among Bedouin and Jewish children. Journal of Peace Education, 6 (1), 69-86. https://doi.org/10.1080/17400200802658407.

Öksüz, Y., Güven, E., Baba, M., \& Kartal, A. (2015). Investigating primary school students' perceptions about differences through their drawings. Turkish Studies International Periodical for the Languages, Literature, and History of Turkish or Turkic, 10(3), 529-544.

Perşembe, E. (2010). Federal Almanya'nın Baden-Württemberg eyaletinde eğitim sistemi ve Türk göçmen çocuklarının eğitim sorunları . Ondokuz Mayıs Üniversitesi İlahiyat Fakültesi Dergisi (29), 55-80.

Pettigrew, T., \& Tropp, L. (2006). A meta-analytic test of intergroup contact theory. Journal of Personality and Social Psychology, 90, 751-783.

Pnevmatikos, D. (2002). Conceptual changes in religious concepts of elementary school children: The case of the house where God lives. Educational Psychology, 22(1), 93-112.

Rotenberg, K.J., \& Cerda, C. (1994). Racially based trust expectancies of Native American and Caucasian children. The Journal of Social Psychology, 134, 621-631.

Sayıl, M. (2004). Çocuk çizimlerinin klinik amaçlı kullanımı üzerine bir değerlendirme. Türk Psikiyatri Yazıları, 7(14), 1-13. 
Seul, J.R. (1999). 'Ours is the Way of God': Religion, Identity, And Intergroup Conflict. Journal of Peace Research, 36(5), 553-569. Retrieved April 12, 2015, from https://doi.org/10.1177/0022343399036005004.

Şen-Beytut, D., Bolışık, B., Solak, U., \& Seyioğlu, U. (2009). Çocuklarda hastaneye yatma etkilerinin projektif yöntem olan resim çizme yolu ile incelenmesi. Maltepe Üniversitesi Hemşirelik Bilim ve Sanat Dergisi, 2(3), 35-44.

Takriti, R. A., Barrett, M., \& Buchanan-Barrow, E. (2006). Children's understanding of religion: Interviews with Arab-Muslim, Asian-Muslim, Christian and Hindu children aged 5-11 years. Mental Health, Religion \& Culture, 9, 29-42.

Teichman, Y. (2001). The development of Israeli children's images of Jews and Arabs and their expression in human figure drawings. Developmental Psychology, 37(6), 749761. https://doi.org/10.1037//0012-1649.37.6.749.

Teichman, Y., \& Zafrir, H. (2003). Images Held by Jewish and Arab Children in Israel of People Representing their Own and the Other Group. Journal of Cross-Cultural Psychology, 34(6), 658-676. Retrieved July 25, 2016, from https://doi.org/10.1177/0022022103256847.

Tümlü, C. (2013). 5-12 yaş aralığındaki çocukların ölüm algısını ifade biçimlerinin incelenmesi. Yayımlanmamış yüksek lisans tezi. İnönü Üniversitesi, Eğitim Bilimleri Enstitüsü, Malatya.

Türkcan, B. (2013). Çocuk resimlerinin analizinde göstergebilimsel bir yaklaşım. Kuram ve Uygulamada Ĕ̈itim Bilimleri, 13(1), s. 585-607.

Türkkan (Türkcan), B. (2008). İlköğretim görsel sanatlar dersi bağlamında görsel kültür çalışmaları: bir eylem araştırması. Yayımlanmamış doktora tezi, Anadolu Üniversitesi Eğitim Bilimleri Enstitüsü, Eskişehir.

Ulçay, H. S. (2011). İlköğretim çağı çocuk resimlerinde cennet ve cehennem tasavvuru. Yayımlanmamış yüksek lisans tezi. Sakarya Üniversitesi, Sosyal Bilimler Enstitüsü, Sakarya.

van der Straten Waillet, N., \& Roskam, I. (2012a). Religious Discrimination in Childhood and Adolescence. Archive for the Psychology of Religion, 34(2), 215-242. Retrieved April 22, 2016, from https://doi.org/10.1163/15736121-12341240. 
van der Straten Waillet, N., \& Roskam, I. (2012b). Developmental and Social Determinants of Religious Social Categorization. The Journal of Genetic Psychology, 173 (2), 208-220. Retrieved April 22, 2016, from https://doi.org/10.1080/00221325.2011.600356.

Velasco González, K., Verkuyten, M., Weesie, J., \& Poppe, E. (2008). Prejudice towards Muslims in the Netherlands: Testing integrated threat theory. British Journal of Social Psychology, 47, 667-685.

Verkuyten, M. (2007). Religious Group Identification and Inter-Religious Relations: A Study Among Turkish-Dutch Muslims. Group Processes \& Intergroup Relations, 10 (3), 341-357. Retrieved April 25, 2017, from https://doi.org/10.1177/1368430207078695.

Verkuyten, M., \& Thijs, J. (2010). Religious Group Relations Among Christian, Muslim and Nonreligious Early Adolescents in the Netherlands. The Journal of Early Adolescence, 30(1), 27-49. Retrieved April 25, 2017, from https://doi.org/10.1177/0272431609342984.

White, F.A., \& Gleitzman, M. (2006). An examination of family socialisation processes as moderators of racial prejudice transmission between adolescents and their parents. Journal of Family Studies, 12(2), 247-260.

Yavuzer, H. (2013). Resimleriyle çocuk "resimleriyle çocuğu tanıma". İstanbul: Remzi Kitabevi.

Yedidia, T., \& Lipschitz-Elchawi, R. (2012). Examining Social Perceptions Between Arab and Jewish Children Through Human Figure Drawings. Art Therapy, 29(3), 104112. https://doi.org/10.1080/07421656.2012.703052.

Yurtal, F., \& Artut, K. (2008). Çocuklarının şiddeti algılama biçimlerinin çizdikleri resimlere yansımaları. Çocuk ve Gençlik Ruh Sağlı̆̆ı Dergisi, 15(3), 149-155.

Zengin, H. K. (2010). Almanya'daki Müslüman çocuklarda Allah kavramının gelişimi: Âdem ve Havva kıssası - yaratılışı, cennetten çıkarılıştan - bağlamında 1-4 ve 6. sınıf çocukları üzerine bir araştırma. Ankara Üniversitesi İlahiyat Fakültesi Dergisi, 51(1), 213-248. 